\title{
EDUKASI DAN SOSIALISASI MENGENAI PELAPISAN KAPAL KAYU DENGAN MENGGUNAKAN MATERIAL FRP
}

\author{
Aang Wahidin ${ }^{1 *}$, Fitri Hardiyanti ${ }^{1}$, Mochamad Yusuf Santoso ${ }^{1}$, Ruddianto ${ }^{1}$, Tri Tiyasmihadi ${ }^{1}$, Gaguk \\ Suhardjito $^{1}$, Mochammad Choirul Rizal ${ }^{1}$ \\ ${ }^{1}$ Politeknik Perkapalan Negeri Surabaya (PPNS) \\ Jalan Teknik Kimia, Kampus ITS Sukolilo - Surabaya, Jawa Timur 60111 \\ email : aangwahidin@ppns.ac.id
}

diterima tanggal : 9 Agustus 2018 disetujui tanggal : 20 November 2018

\begin{abstract}
ABSTRAK
Pada tahun 2010 Kementrian kelautan dan perikanan Republik Indonesia memiliki program pemberian bantuan kepada nelayan berupa kapal ikan. Kapal tersebut berbahan dasar fiberglass atau bisa disebut dengan material Fiberglass reinforced Plastic (FRP) dan kayu. Desa Tanjung Widoro merupakan pesisir yang terletak didaerah kepulauan Mengare yang berada di kabupaten Gresik. Mayoritas pekerjaan utama masyarakat daerah tersebut yaitu sebagai nelayan. Kapal yang digunakan daerah tersebut yaitu kapal kayu yang pada umumnya kapal tersebut harus melakukan docking kapal 2 kali dalam satu bulan. Proses docking ini membutuhkan waktu 2-3 hari yang tentunya menghambat kegiatan nelayan untuk mencari ikan. Sampai saat ini nelayan di daerah Mengare tidak mau menggunakan kapal pemberian dari pemerintah karena masyarakat nelayan masih meyakini bahwa kapal kayu lebih kuat daripada kapal FRP. Sehingga untuk memperkenalkan material FRP kepada masyarakat perlu dilakukan pelatihan tentang penggunaan material FRP untuk bahan perkuatan kapal kayu. Diharapkan pelatihan ini nantinya mampu merubah pemikiran masyarakat dan membuat nelayan mau beralih ke kapal FRP. Fiberglass juga diharapkan mampu memperkuat kapal kayu yang saat ini digunakan oleh nelayan dan akan mampu mengurangi waktu docking kapal. Inovasi ini merupakan pelapisan kayu dengan mengunakan material fiber atau biasa disebut dengan "komposit sandwich".
\end{abstract}

Kata kunci: pelatihan, pelapisan kapal, FRP, komposit sandwich

\section{ABSTRACT}

In 2010, the Ministry of Maritime Affairs and Fisheries of the Republic of Indonesia had an aid program for fishing boats. The ship is made from fiberglass or can be called Fiberglass reinforced Plastic (FRP) and wood. Tanjung Widoro village is a village located in Gresik Regency with majority people are work as fishermen. The ships that they used are wooden ships which must be docked twice in one month. This docking process takes 2-3 days that inhibit the fishing activity. To date, fishermen in Mengare area do not want to use ships from the government because the fishing community was still convinced that wooden boats were stronger than FRP vessels. In order to introduce FRP materials to the community, training needs to be carried out on the use of FRP materials for wood vessel reinforcement materials. It is hoped that this training will be able to change people's thinking and make fishermen want to switch to FRP vessels. Fiberglass is also expected to be able to strengthen wooden ships that are currently used by fishermen and will be able to reduce ship docking time. This innovation is wood coating using fiber material or commonly called sandwich composite.

Keyword: : training, ship coating, frp, sandwiches composite 


\section{PENDAHULUAN}

Berbagai jenis kapal laut digunakan dalam penagkapan ikan komersial, olahraga, maupun rekreasi. Pada tahun 2004, di Indonesia terdapat setidaknya empat juta kapal penangkap ikan komersial. Sekitar 1,3 juta merupakan kapal yang memiliki geladak. Hampir semua kapal bergeladak ini sudah termekanisasi dan 40 ribu diantaranya berbobot lebih dari 100 ton. Sekitar dua per tiga dari empat juta kapal tersebut merupakan perahu penangkap ikan tradisional dengan berbagai tipe, digerakkan dengan layar dan dayung. Perahu jenis tersebut biasanya digunakan oleh nelayan tradisional terpencil [1].

Pada tahun 2010 Kementrian kelautan dan perikanan Republik Indonesia memiliki program pemberian bantuan kepada nelayan berupa kapal ikan. Kapal tersebut berbahan dasar fiberglass atau bisa disebut dengan material Fiberglass reinforced Plastic (FRP) dan kayu. Program ini didominasi bantuan kepada nelayan berupa kapal fiberglass dengan perbandingan 1000 kapal FRP dengan 400 kapal kayu [2]. Tujuan dari pemerintah adalah untuk mengenalkan material baru kepada masyarakat dalam pembangunan kapal. Hal ini dikarenakan material kayu yang menjadi material utama pembuatan kapal ikan nelayan mulai langka. Kondisi indonesia sebagai negara maritim juga membuat kapal ikan merupakan kapal yang sangat dibutuhkan masyarakat sebagai salah satu alat mata pencaharian.

Desa Tanjung Widoro merupakan pesisir yang terletak didaerah kepulauan Mengare yang berada di kabupaten Gresik. Mayoritas pekerjaan utama masyarakat daerah tersebut yaitu sebagai nelayan. Jumlah nelayan yang terdapat pada desa ini sekitar 460 nelayan. Penghasilan yang didapatkan oleh nelayan untuk sekali jalan ratarata Rp. 150.000,00 jika musim bagus. Sedangkan jika musim jelek, pendapatan menurun menjadi Rp. 50.000,00 sekali jalan. Umumnya masyarakat daerah tersebut menggunakan kapal sebagai sarana transportasi utama sehari-hari. Kapal yang digunakan daerah tersebut yaitu kapal kayu yang pada umumnya kapal tersebut harus melakukan docking kapal 2 kali dalam satu bulan. Proses docking ini membutuhkan waktu 2-3 hari yang tentunya menghambat kegiatan nelayan untuk mencari ikan. Gambar 1 menunjukkan kapal yang digunakan oleh masyarakat nelayan setempat.

[2,5] saat ini nelayan di daerah Mengare tidak mau menggunakan kapal pemberian dari pemerintah karena masyarakat nelayan masih meyakini bahwa kapal kayu lebih kuat daripada kapal FRP. Sehingga untuk memperkenalkan material FRP kepada masyarakat perlu dilakukan pelatihan dimana material FRP digunakan untuk bahan perkuatan kapal kayu. Diharapkan pelatihan ini nantinya mampu merubah pemikiran masyarakat dan membuat nelayan mau beralih ke kapal FRP. Fiberglass juga diharapkan mampu memperkuat kapal kayu yang saat ini digunakan oleh nelayan dan akan mampu mengurangi waktu docking kapal. Inovasi ini merupakan pelapisan kayu dengan mengunakan material fiber atau biasa disebut dengan "komposit sandwich". Metode ini dengan cara menempelkan dua kulit tipis namun kaku dengn inti tebal yang ringan. Beberapa bahan inti yang umum digunakan adalah kayu, sarang lebah, rangka, struktur bergelombang, dan busa sel terbuka atau tertutup, dan berbagai bahan lainnya [3]. Sandwich komposit biasanya digunakan untuk dirgantara, kelautan, dan aplikasi struktural lainnya termasuk berbagai jenis transportasi kendaraan dan kemasan. Busa merupakan sintetis merupakan salah satu inti material sandwich yang sangat penting sebagai inti bahan komposit sandwich. Hal ini dikarenakan kompresinya yang tinggi, kuat, toleransi kerusakan besar, dan penyerapan kelembaban rendah [4].

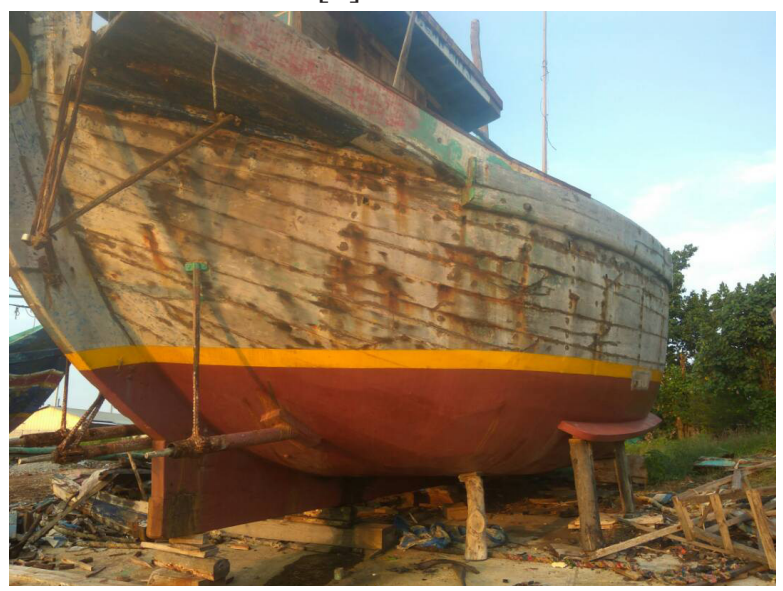

Gambar 1. Kapal Ikan daerah Mengare

\section{METODE}


Identifikasi kebutuhan pada mitra dilakukan untuk mengetahui jenis kapal yang selama ini digunakan nelayan. Selain itu, data maintenance kapal dibutuhkan untuk mengetahui pelaksanaan perbaikan kapal yang selama ini dilakukan oleh nelayan Desa Tanjung Widoro. Informasi dari data-data tersebut digunakan untuk menentukan material FRP yang cocok digunakan untuk mitra.

Pada tahapan pelaksanaan pelatihan akan dilaksanakan dua sub kegiatan, yaitu seminar dan praktek pelapisan kapal. Seminar dilaksanakan untuk memberikan pengetahuan kepada nelayan tentang material FRP dan keunggulannya. Selain itu, perbandingan material yang diusulkan dengan material yang selama ini digunakan oleh nelayan juga akan disampaikan. Peserta seminar juga akan mendapatkan pengetahuan mengenai teknik pelapisan kapal nelayan dengan material FRP yang diusulkan. Hal menarik lainnya yang akan disampaikan saat seminar adalah analisa teknis dan ekonomis pelapisan kapal nelayan menggunakan FRP. Setelah melaksanakan seminar, peserta pelatihan akan ditunjukkan cara pelapisan kapal dengan teknologi FRP.

Setelah pelaksaan pelatihan, tahapan selanjutnya adalah melakukan analisa hasil perlatihan.Analisadilakukanuntukmengetahui apakah masyarakat sudah mendapatkan peningkatan pemahaman tentang pelapisan kapal dengan material FRP. Selain itu, analisa dilakukan untuk mendapatkan informasi mengenai penerapan pelatihan masa kegiatan perbaikan kapal nelayan. Penyusunan laporan dilakukan sejalan dengan tahapan analisa hasil pelatihan hingga kegiatan pengabdian ini selesai.

\section{HASIL DAN PEMBAHASAN}

\subsection{Survey Lokasi}

Sebelum melaksanakan kegiatan pengabdian masyarakat terlebih dahulu dilakukan survey di desa Mengare, Gresik untuk mengetahui lokasi tempat melaksanakan pengabdian dan membangkitkan minat masyarakat untuk mengikuti kegiatan edukasi pelapisan kapal kayu. Setelah bertemu dengan masyarakat maka disepakati tanggal pelaksanaan pengabdian yaitu hari minggu tanggal 23 Sepetember 2018 bertempat di balai desa Mengare, Gresik.

\subsection{Pelaksanaan}

Pertemuan tatap muka dilakukan dengan metode ceramah dan demonstrasi, dilanjutkan latihan/praktek untuk melapisi kapal kayu dengan material FRP, mulai dari pembersihan dan pengeringan kayu, melapisi dengan serat fiber, hingga pendempulan dan penghalusan. Untuk praktek tidak dapat menggunakan kapal kayu dikarenakan keterbatasan waktu, sehingga dilakukan demonstrasi pada papan kayu yang nantinya masyarakat dapat menerapkan langsung pada kapal mereka. Pokok bahasan yang disampaikan mengenai:

1. Teori FRP sekaligus mengenalkan material FRP kepada Masyarakat

2. Teori tentang proses pelapisan kapal kayu dengan FRP

3. Penelitian Sebelumnya yang mendukung Pelapisan dengan FRP

4. Praktik pelapisan kayu dengan material FRP.

Kegiatan yang diawali dengan ceramah, seperti yang ditunjukkan pada Gambar 2, mengenai alasan pelapisan kapal kayu dengan FRP, secara garis besar kapal kayu yang selalu terendam di air laut ataupun payau dan selalu terkena matahari secara terus menerus mengakibatkan kapal kayu sangat mudah rusak untuk waktu yang tidak terlalu lama. Perawatan kapal kayu semakin lama semakin mahal karena banyaknya papan kayu yang harus diganti karena pelapukan dan pengurangan ketebalan kulit lambungnya.

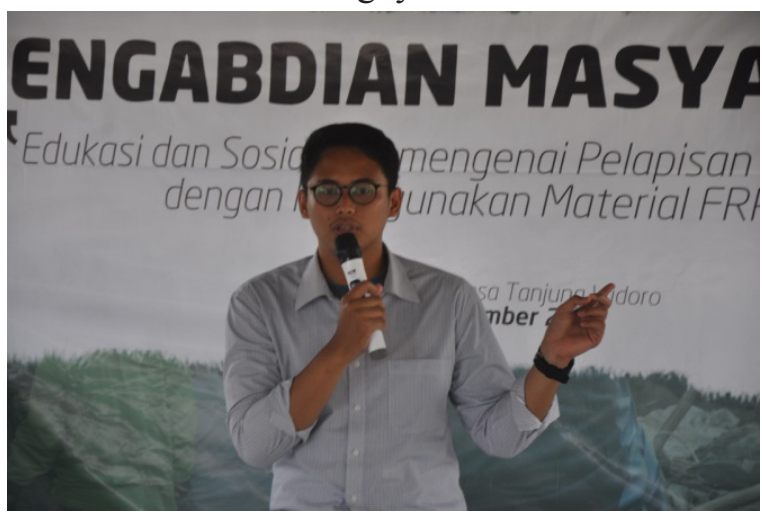

Gambar 2. Ceramah materi pelapisan kapal kayu 


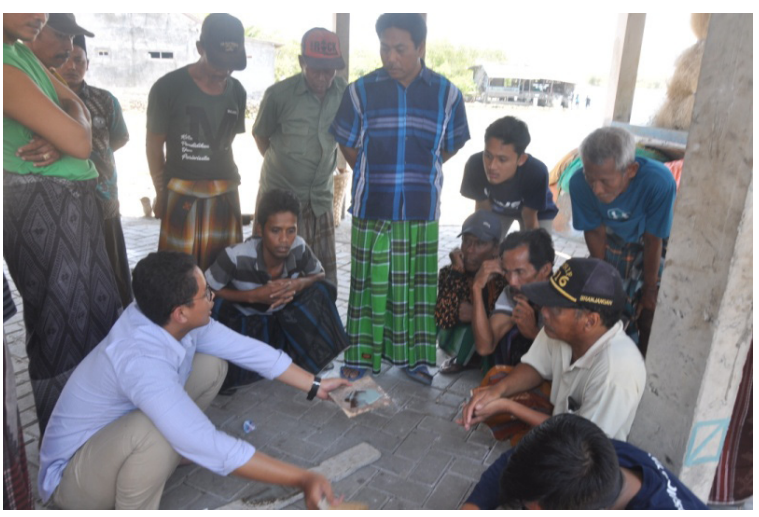

Gambar 3. Praktek pelapisan kayu

Selanjutnya teori tentang FRP, mengenalkan material yang digunakan dalam laminasi kapal kayu dengan laminasi fiberglass ini adalah:

- Kapal kayu,

- Resin Yulac157,

- Chopped strand mat (CSM),

- Talk,

- Pigment (pewarna),

- Katalis.

Tabel 1. Perhitungan Biaya Pelapisan (Ramadan dkk, 2018)

\begin{tabular}{|l|l|l|l|}
\hline No. & Variasi & Schedule Laminasi & $\begin{array}{l}\text { Total Biaya } \\
(\mathrm{Rp})\end{array}$ \\
\hline 1 & A & $\begin{array}{l}\text { Laminas kayu den- } \\
\text { gan matt 300 tanpa } \\
\text { lem epoxy }\end{array}$ & 15.455 .184 \\
\hline 2 & B & $\begin{array}{l}\text { Laminas kayu } \\
\text { dengan matt 300 } \\
\text { dengan lem epoxy }\end{array}$ & 22.842 .268 \\
\hline 3 & C & $\begin{array}{l}\text { Laminas kayu 3 } \\
\text { dengan lembar matt } \\
\text { 300 dan 1 lembar } \\
\text { WR 450 tanpa } \\
\text { menggunakan lem } \\
\text { epoxy }\end{array}$ & 31.308 .060 \\
\hline 4 & D & $\begin{array}{l}\text { Laminas kayu 3 } \\
\text { dengan lembar matt } \\
300 \text { dan 1 lembar } \\
\text { WR 450 dengan } \\
\text { menggunakan lem } \\
\text { epoxy }\end{array}$ & 38.695 .560 \\
\hline
\end{tabular}

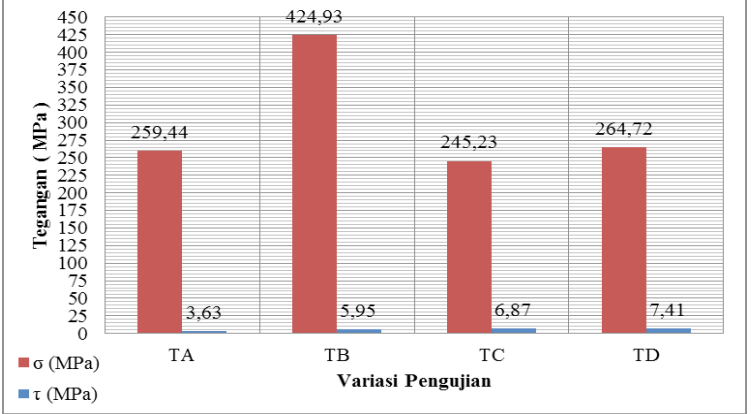

Gambar 4. Hasil analisa teknis (Ramadan dkk, 2018)

Terakhir, menunjukkan bukti hasil penelitian (Ramadan dkk, 2018) pada Tabel 1 kepada masyarakat. Hasil penelitian yang dimaksud adalah pengujian teknis dan ekonomis dengan variasi pelapisan kayu yang berbeda dan pemanfaatan pelapisan kapal kayu dengan menggunakan FRP. Dari hasil penelitian (Ramadan dkk, 2018) disebutkan bahwa biaya yang harus dikeluarkan untuk melaminasi satu kapal dengan varisai bahan dan pelapisan yang berbeda. Meskipun terlihat membutuhkan biaya yang cukup besar untuk pelapisan, akan tetapi untuk beberapa tahun kedepan akan menghemat biaya yang akan dikeluarkan untuk docking setiap bulan apabila tidak dilapisi dengan FRP. Selain itu juga ditunjukkan hasil pengujian teknis dari berbagai variasi material seperti pada Gambar 4.

Grafik pada Gambar 4 menunjukkan bahwa nilai teknis dari variasi material B lebih baik dibanding variasi material lainnya. Dari pemberian teori ini tampak bahwa masyarakat belum mengenal tentang FRP dan material-material penyusunnya. Sesi ceramah juga dilakukan dengan tanya jawab terkait kendala- kendala masyarakat menggunakan kapal kayu. Berbagai pertanyaan diajukan secara antusias oleh Masyarakat dalam sesi tanya jawab. Secara garis besar inti dari pertanyaan para peserta adalah:

1. Alasan mengapa kapal kayu dilapisi material FRP

2. Langkah-langkah pelapisan kapal kayu dengan material FRP

3. Biaya yang mungkin dikeluarkan untuk melakukan pelapisan dengan FRP pada setiap kapal nelayan

4. Bagaimana penggunaan material-material 
penyusun FRP seperti resin dan katalis.

Sebagian besar pertanyaan dilontarkan masyarakat pada sesi praktik pelapisan kayu, mulai dari proses dan fungsi masing-masing material penyusun FRP.

Program pengabdian pada masyarakat berupa edukasi pelapisan kapal kayu dengan material FRP di desa Mengaree, telah dilaksanakan dan diharapkan dapat menambah pengetahuan dan keterampilan masyarakat yang berprofesi sebagai nelayan. Selain itu diharapkan masyarakat dapat mempraktikan sendiri hasil pengabdian ini guna menurunkan biaya yang mereka keluarkan setiap bulan untuk perawatan/docking kapal kayu. Dengan pelapisan kapal kayu maka akan melindungi lambung kapal kayu dari merembesnya air ke dalam kapal dan memperkuat konstruksi antar papan di lambung kapal.

\section{KESIMPULAN}

Secara keseluruhan kegiatan ini dapat dikatakan berhasil. Keberhasilan ini selain diukur dari materi yang disampaikan dan kepuasan peserta setelah mengikuti kegiatan ini. Antusiasme masyarakat dan harapan mereka kedepan adalah adanya kegiatan lanjutan terkait materi ini dengan waktu yang panjang dan sehingga masyarakat bisa belajar melalui praktik pada kapal mereka. Manfaat yang diperoleh masyarakat adalah dapat menurukan biaya yang mereka keluarkan untuk docking setiap bulan dan memperkuat kapal mereka. Selain biaya docking, apabila kapal melakukan repair maka nelayan tidak dapat mencari ikan hal ini akan berpengaruh terhadap pendapatan. Diharapkan dengan pelapisan dengan FRP ini maka setiap bulan nelayan tidak perlu repair dan mereka akan dapat mencari ikan. Hal ini akan berkaitan dengan pendapatan mereka juga akan bertambah dengan kualitas kualitas kapal yang lebih baik.

\section{DAFTAR PUSTAKA}

[1] Food and Agriculture Organization of The United Nations (FAO), "The World's Mangroves 1980-2005" Forests Resources Assesment Working Paper No.153, 2007.

[2] Kementrian Kelautan dan Perikanan RI (KKP), " Daftar Rincian Alokasi kapal Ikan Inka mina Berdasarkan Provinsi/Kabupaten/ Kota. jakarta: Kementrian kelautan dan perikanan", 2013.

[3] Vinson, JackR. The behavior of sandwich structures of isotropic and composite materials. Routledge, 2018.

[4] A.J Hodge, R. K., "Sandwich Composite, Synthetic Fom Core based aplications for space structure", 45 international SAMPE Symposium, pp. 2293-2304, 2000.

[5] Y. C. Ramadan, I. P. Arta, F. Hardiyanti, “ Analisis Teknis dan Ekonomis Pelapisan Material Fiber Reinforced Plastic pada Kapal Ikan Tradisional 20-GT Menggunakan Metode Hand Lay Up", Seminar MASTER PPNS, 2018.

[6] A. P. Nugroho, "Optimasi Tata Letak Area Produksi Galangan Kapal Fiberglass", Skripsi Fakultas teknik Universitas Indonesia, 2012. 
Halaman ini sengaja dikosogkan 